Int. Archs Allergy appl. Immun. 1987;82:225-230

\title{
Contents, Vol. 82, No. 3-4, 1987
}

\section{Festschrift for Paul Kallós}

New Aspects of Allergic Diseases, Immunoregulation and Immunodeficiencies

16th Symposium of the Collegium Internationale Allergologicum, Göteborg, August 17-21,1986

Editors:

L.A. Hanson, Göteborg S. Ahlstedt, Uppsala N.B. Lindholm, Göteborg

139 figures, 1 color plate, 59 tables, 1987

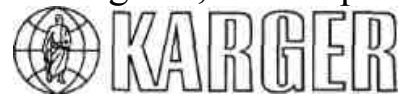

Transactions of the Collegium Internationale Allergologicum

15th Symposium, Puerto Vallarta, 1984

Pathology and Physiology of Allergic Reactions

'International Archives of Allergy and Applied Immunology', Vol. 77, No. 1-2 (1985) Editor:

Norman, P.S. (Baltimore, Md.) 280 p., 89 fig., 62 tab., 1985 ISBN 3-8055-4056-6

14th Symposium, Sorrento, 1982 Progress in Clinical Immunology

'Monographs in Allergy', Vol. 18 (1983)

Editors: Ricci, M. (Florence) and Marone, G. (Naples)

$\mathrm{X}+314$ p., 60 fig., 46 tab., 1983

ISBN 3-8055-3697-6

13th Symposium, Konstanz, 1980 Cellular Interactions in Allergy

'International Archives of Allergy and Applied Immunology', Vol. 66, Suppl. 1 (1981) Editors:

Kristensen, F. (Bern); de Week, A.L. (Bern) and Dukor, P. (Basel) VI + 298 p., 112 fig., 66 tab., 1981 ISBN 3-8055-3439-6

1st-12th Symposium, please ask for details

S. Karger · Medical and Scientific Publishers — Basel · München · Paris — London · New York · New Delhi $\cdot$ Singapore $\cdot$ Tokyo $\cdot$ Sydney

Drug Dosage

The authors and the publisher have exerted every effort to ensure that drug selection and dosage set forth in this text are in accord with current recommendations and practice at the time of publication. However, in view of ongoing research, changes in government regulations, and the constant flow of information relating to drug therapy and drug reactions, the reader is urged to check the package insert for each drug for any change in indications and dosage and for added warnings and precautions. This is particularly important when the recommended agent is a new and/or infrequently employed drug.

All rights reserved.

No part of this publication may be translated into other languages, reproduced or utilized in any form or by any means, electronic or mechanical, including photocopying, recording, microcopying, or by any information storage and retrieval system, without permission in writing from the publisher or, in the case of photocopying, direct payment of a specified fee to the Copyright Clearance Center (see 'Information for Readers and Subscribers'). 
(C) Copyright 1987 by S. Karger AG, P.O. Box, CH-4009 Basel (Switzerland) Printed in Switzerland by Buchdruckerei Basler Zeitung AG, Basel ISBN 3-8055-4568-1

Contents

231

In Honour of Paul Kallós

Dukor, $\mathrm{P}$

Carl Prausnitz Memorial Lecture

Immunoprecipitation in Court - The Chamberlain Case

Ouchterlony, Ö 233

Analysis of Mast Cell Function in Biological Responses Not Involving IgE

Galli, S.J.; Wershil, B.K.; Mekori, Y.A 269

Anti-Idiotypic Antibodies as Staphylococcal Enterotoxin Receptor Probes on Monkey Mast Cells Bamberger, U.; Scheuber, P.H.; Sailer-Kramer, B.;

Hammer, D.K

272

Immune-Related Cellular Responses in Mucosal Membrane

Mast Cells

The Role of Mast Cells in Inflammatory Processes: Evidence for Nerve/Mast Cell Interactions Bienenstock, J.; Tomioka, M.; Matsuda, H.; Stead, R.H.; Quinonez, G.; Simon, G.T.; Coughlin, M.D.; Denburg, J.A. 238

Mutual Phenotypic Changes between Connective

Tissue Type and Mucosal Mast Cells

Kitamura, Y.; Kanakura, Y.; Sonoda, S.; Asai, H.;

Nakano, T 244

Mucosal Mast Cells in the Rat and in Man

Enerbäck, L 249

Investigations of Rat Mast Cell Heterogeneity

Befus, D.; Swieter, M.; Fujimaki, H.; Lee, T 256

In vivo Increase of Cutaneous Mast Cells in Response

to Specific Mediators and Ascaris Antigen

Czarnetzki, B.M.; Mecklenburg, G 259

Beige Mouse Mast Cells Generated in vitro:

Ultrastructural Analysis of Maturation Induced by Sodium Butyrate and of IgE-Mediated,

Antigen-Dependent Degranulation

Dvorak, A.M.; Hammel, I.; Galli, S.J 261

Changes in Nasal Mast Cell Numbers In and Out of

the Pollen Season

Viegas, M.; Gomez, E.; Brooks, J.; Davies, R.J

275

Seasonal Variation of Mast Cell Function in

Human Adenoid Tissues

Schmutzler, W.; Amandi, M.; Aniol, M.; Braam, U.;

Eichelberg, D.; Greven, T.; Kortemeier, A.; Schmitz, F.J.;

Ziesche, R 277

Mast Cell Histamine Release Induced by Intermediate Products of Arachidonic Acid Metabolism 
Masini, E.; Palmerani, B.; Bani-Sacchi, T.; Giannella, E.;

Fantozzi, R.; Mannaioni, P.F 279

Time-Course of IgE Binding to Rat Peritoneal

Cells after Sensitization with Alum-Adsorbed

Ovalbumin and Bordetella pertussis

Behrendt, $\mathrm{H}$

283

Staphylococcal Enterotoxin B as a Nonimmunological Mast Cell Stimulus in Primates: The Role of Endogenous Cysteinyl Leukotrienes

Scheuber, P.H.; Denzlinger, C; Wilker, D.; Beck, G.;

Keppler, D.; Hammer, D.K 289

The Role of Histamine in Allergen and Adenosine-Induced Bronchoconstriction

Rafferty, P.; Beasley, R.; Southgate, P.; Holgate, S 292

228

Contents

Purification of Serum Proteins with Inhibitory Activity on the Histamine Release in vitro and/or in vivo Theobald, K.; Gross-Weege, W.; Keymling, J.; Kònig, W. . 295

The Mast Cell and Signs of Pulmonary Fibroblast Activation in Sarcoidosis Bjermer,

L.;Engström-Laurent, A.;Thunell, M.;Hällgren, R. 298

Macrophages and Thrombocytes

Accessory Molecules in T Lymphocyte Activation

Miller, J.F.A.P302

Platelets as Effectors in Immune and Hypersensi-tivity Reactions

Capron, A.; Joseph, M.; Ameisen, J.C.; Capron, M.;

Pancré, V.; Auriault, C 307

Thromboxane B2 Synthesis in Human Platelets

Induced by the Late Complement Components

C5b-9

Betz, ML; Seitz, ML; Hänsch, G.M 313

Effect of the Late Complement Components C5b-9

on Human Monocytes: Release of Prostanoids,

Oxygen Radicals and of a Factor Inducing Cell

Proliferation

Hänsch, G.M.; Seitz, M.; Betz, M 317

Basophils and Eosinophils

Contribution of Basophil/Mast Cell and Eosinophil

Growth and Differentiation to the Allergic Tissue

Inflammatory Response

Denburg, J.A.; Otsuka, H.; Ohnisi, M.; Ruhno, J.;

Bienenstock, J.; Dolovich, J 321

Activation of Basophils and Mast Cells for Mediator Release

Ishizaka, T.; White, J.R.; Saito, H 327

Eosinophil Activation in Allergic Disease

Venge, P.; Håkansson, L.; Peterson, C.G.B 333 
Biochemical Characterization of the Human

Basophil-Promoting Activity

Stadler, B.M.; Hirai, K.; Brantschen, S.; Nakajima, K.;

Weck,A.L. de 338

Mediator Release from Basophilic Cells Derived

from Cultured Cord Blood Cells

Iikura, Y.; Nagakura, T.; Nakamura, N.; Shichijo, K.;

Saito, N $\quad 341$

Nonsteroidal Antiinflammatory Drugs Induce UV-Dependent Histamine and Leukotriene

Release from Peripheral Human Leukocytes

Ring, J.; Przybilla, B.; Ruzicka, T 344

Airway Hyper-Reactivity and Eosinophilia in Rats

Treated with Sephadex Particles

Laycock, S.M.; Smith, H.; Spicer, B.A 347

Eosinophil Chemotactic Activity in Allergic Patients

during the Birch Pollen Season: The Effect of

Immunotherapy

Rak, S.; Håkansson, L.; Venge, P 349

Goblet Cells

Structure and Function of Intestinal Mucin: Developmental Aspects

Snyder, J.D.; Walker, W.A 351

Immune Regulation of Goblet Cell Development

Ahlstedt, S.; Enander, 1357

Regulation of the Delayed Hypersensitivity

Reaction in the Lung Reflected as Mononuclear,

Mast Cell and Mucus Cell Appearance after

T Helper Cell Depletion and Adoptive Transfer

Enander, I.; Ulfgren, A.-K.; Nygren, H.; Holmdahl, R.;

Klareskog, L.; Larsson, P.; Ahlstedt, S 361

Interleukin-1 Induces Mucus Secretion from Mouse Intestinal Explants Han, V.; Resau, J,

Prendergast, R.; Scott, A.; Levy, D.A. . 364

Neurotransmitters and Immune Reactivity

Substance P and Calcitonin Gene-Related Peptide:

Effects on Mast Cells and in Human Skin

Foreman, J.C 366

Inflammatory Mediators, Tachykinins and Enkeph-alinase in Airways Lazarus, S.C.; Borson,

D.B.; Gold, W.M.; Nadel, J.A. ... 372

Effect of Capsaicin on Bronchial Reactivity and Inflammation in Sensitized Adult Rats Alving,

K.; Ulfgren, A.-K.; Lundberg, J.M.; Ahlstedt, S. . 377

Chemiluminescence Response of Polymorpho-

nuclear Leukocytes in Atopic Dermatitis

Schöpf, E.; Kapp, A 380

Regulation of $1 / 8$ E Mediated Disorders

T Cell Factors Involved in the Regulation of the IgE Synthesis

Ishizaka, K.; Jardieu, P.; Akasaki, M.; Iwata, M 383

Regulation of the Human Allergic Response 
Geha, R.S.; Leung, D.Y.M 389

Recombinant Human IgE

Gould, H.J.; Helm, B.A.; Marsh, P.J.; Geha, R.S

392

Contents

229

Functional Heterogeneity within the Human

Peripheral Blood B Cell Pool Engaged in IgE

Synthesis

Turner, K.J.; Holt, B.J.; Cameron, K.J.; Holt, P.G 394

Seasonal Variations in in vitro Synthesis of Rye Pollen-Specific IgE by Human Peripheral

Mono-nuclear Cells. Functional Heterogeneity within the IgE-B Pool

Turner, K.J.; Siemensma, N.P.; Krska, K.; Cameron, K.J. 398

Synthesis and Regulation of the IgE Receptor on B

Lymphocyte Cell Lines

Conrad, D.H.; Keegan, A.; Rao, M.; Lee, W.T 402

Human T Hybridoma-Derived Immunoglobulin-Binding Factors

Stadler, B.M.; Gauchat, D.; Hildbrand, M.-L.; Yang, X.;

Weck,A.L. de 405

Generation of Cell-Derived Factors in vitro Which

Modulate IgE Synthesis

Pfeiffer, P.; Rauschen, I.; Bujanowski, J.; König, W 408

In vitro IgE Synthesis Induced by Human T Cell Clones in Normal B Cells and Its Suppression by Heterogenous T Cell Populations Romagnani, S.; Del Prete, G.F.; Maggi, E.; Ricci, M. ... 411

A Mechanism for the Suppression of Ongoing IgE

Synthesis

Sherr, E.H.; Saxon, A 414

Effects of Cyclophosphamide Treatment and

Gamma Irradiation of SJL Mice on the IgE Antibody Response and the Nature of IgE-Binding

Factors

Akasaki, M.; Ishizaka, K 417

Natural Killer Cell Interaction with IgE in the

Control of Ongoing Human IgE Synthesis

Kimata, H.; Saxon, A 419

Essential Fatty Acids in Serum Lecithin of Children with Atopic Dermatitis and in Umbilical

Cord Serum of Infants with High or Low IgE Levels

Strannegård, I.-L.; Svennerholm, L.; Strannegård, Ö. ... 422

Occupational Allergies

Current Concepts in the Pathogenesis of Occupa-

tionally Induced Allergic Pneumonitis

Salvaggio, J.E 424

Acid Anhydrides and Asthma

Newman Taylor, A.J.; Venables, K.M.; Durham, S.R.;

Graneek, B.J.; Topping, M.D 435

Sawmill Alveolitis in Sweden

Belin,L $\quad 440$ 
Physicochemical Characterization of a Major Protein Allergen, Derp I, from the House Dust Mite, Dermatophagoides pteronyssinus. Amino Acid Analysis and Circular Dichroism Studies Stewart, G.A.; Simpson, R.J.; Thomas, W.R.; Turner, K.J. 444

Level of Indoor Allergens in Dust from Homes of Allergic and Non-Allergic Individuals

Schwartz, B.; Lind, P.; Løwenstein, H

Allergy to Laboratory Animals: Characterization and Source of Two Major Mouse Allergens, Ag 1 and $\mathrm{Ag} 3$

Longbottom, J.L.; Price, J.A 450

Percutaneous Sensitisation to House Dust Mite

May Occur Naturally in Eczema

Carswell, F.; Thompson, S.J 453

The Relationship between Total Serum IgE and Castor Bean-Specific IgE Antibodies in Castor Bean-Sensitive Patients from Marseilles Thorpe, S.C.; Kemeny, D.M.; Panzani, R.; Lessof, M.H. .456

Side Chain-Specific Lymphocyte Responses in

Workers with Occupational Allergy Induced by

Penicillins

Stejskal, V.D.M.; Forsbeck, M.; Olin, R 461

Antigenic Challenge via the Airway Alters the

Permeability of the Trachea in Sensitized Rats

Carswell, F.; Mukherjee, S.; Heap, P 465

A Canine Model for the Study of Hapten-Specific

Suppression of IgE-Mediated Bronchoconstric-

tion and Anaphylaxis

Kepron, W.; Jackson, C.-J.; Sehon, A.H 468

Primary and Secondary Immunodeficiency

HTLV-III/LAV and the Origin and Pathogenesis of AIDS

Gallo, R.C.; Robert-Guroff, M.; Wong-Staal, F.;

Reitz, M.S., Jr.; Arya, S.K.; Streicher, H.Z 471

Immunoglobulin G Subclass Deficiencies

Söderström, T.; Söderström, R.; Avanzini, A.;

Brandtzaeg, P.; Karlsson, G.; Hanson, L.Å 476

Immunohistochemical Study of Nasal Mucosa in Patients with Common Variable

Immunodeficiency

Karlsson, G.; Brandtzaeg, P.; Hansson, G.; Petruson, B.;

Björkander, J.; Hanson, L.Å 481

230

Contents

Immunohistochemical Study of Nasal Mucosa in Patients with Selective IgA Deficiency (with 1 color plate)

Brandtzaeg, P.; Karlsson, G.; Hansson, G.; Petruson, B.;

Björkander, J.; Hanson, L.A 483 
Comparison of the Frequency of Atopic Diseases in Children with Severe and Partial IgA

Deficiency

Plebani, A.; Monafo, V.; Ugazio, A.G.; Monti, C;

Avanzini, M.A.; Massimi, P.; Burgio, G.R 485

Screening for Anti-HTLV-III/LAV Antibody in High-Risk Subjects: Sensitivity and Specificity of Commercial Tests

Lantin, J.P.; Peitrequin, R.; Frei, P.C 487

Effect of Growth Factors on the Proliferation of Thymocytes in Different Functional and

Anatomical Compartments

Sandberg, G.; Ernström, U.; Söder, O.; Kölare, S 490

New Advances in Immunopharmacology of Allergic Diseases

Pharmacology of Upper Airways Challenge

Proud, D.; Kagey-Sobotka, A.; Naclerio, R.M.;

Lichtenstein, L.M 493

Primary and Secondary Effector Cells in the

Pathogenesis of Bronchial Asthma

Holgate, S.T.; Twentyman, O.P.; Rafferty, P.; Beasley, R.;

Hutson, P.A.; Robinson, C; Church, M.K 498

Some Studies on Human Pulmonary Mast Cells

Obtained by Bronchoalveolar Lavage and by

Enzymic Dissociation of Whole Lung Tissue

Pearce, F.L.; Flint, K.C.; Leung, K.B.P.; Hudspith, B.N.;

Seager, K.; Hammond, M.D.; Brostoff, J.;

Geraint-James, D.; Johnson, N.Mel 507

The Development of a New Agent for the

Treatment of Inflammatory/Allergic Conditions

Cairns, H.; Orr, T.S.C 513

Mechanisms in Asthma Using the Technique of Bronchoalveolar Lavage

Wardlaw, A.J.; Collins, J.V.; Kay, A.B 518

The Role of Leukotriene-Inducing and

-Metabolizing Enzymes in Inflammation

König, W.; Bremm, K.D.; Brom, H.J.; Roller, M.;

Knöller, J.; Raulf, M.; Schönfeld, W.; Stüning, M 526

Betamethasone Modulates the Biological Function of Human Polymorphonuclear Leukocytes

Marone, G.; Siri, L.; Genovese, A.; Condorelli, M 532

Antiasthmatic Effects of Onions. Inhibition of Platelet-Activating Factor-Induced Bronchial

Obstruction by Onion Oils

Dorsch, W.; Ettl, M.; Hein, G.; Scheftner, P.; Weber, J.;

Bayer, T.; Wagner, H 535

Application of Histamine-Induced Conjunctivitis to the Assessment of a Topical Antihistamine,

Levocabastine

Feinberg, G.; Stokes, T.C 537

Effect of Thromboxane A2 Synthetase Inhibitor on

Immediate-Type Hypersensitivity Reactions

Nakagawa, T.; Miyamoto, T.; Urata, C; Mano, K.;

Yukawa, T.; Makino, S 539 
Effect of a New Selective H i Receptor Antagonist (Levocabastine) in a Nasal and Conjunctival Provocation Test

Pécoud, A.; Zuber, P.; Kolly, M 541

Antagonism of Picumast and Ketotifen against

Histamine, Acetylcholine, LTC4, Slow-Reacting

Substance of Anaphylaxis and Barium Chloride

in the Guinea Pig Ileum Bioassay

Wilhelms, O.-H 544

Inhibition Profiles of Picumast and Ketotifen on the in vitro Release of Prostanoids, Slow-

Reacting Substance of Anaphylaxis, Histamine and Enzyme from Human Leukocytes and Rat Alveolar Macrophages

Wilhelms, O.-H 547

Double-Blind, Placebo-Controlled Immunotherapy

with a High-Molecular-Weight, Formalinized

Allergoid in Grass Pollen Allergy

Bousquet, J.; Frank, E.; Soussana, M.; Hejjaoui, A.;

Maasch, H.J.; Michel, F.-B 550

Asthma and Serum IgE Levels in Children in a Desert Country

Strannegård, I.-L.; Strannegård, Ö 553

Author Index 555 